Jadwiga Gracla

Uniwersytet Warszawski

Wydział Lingwistyki Stosowanej

Katedra Rusycystyki

tel.: +48225534228

e-mail: j.gracla@uw.edu.pl

ORCID ID: https://orcid.org/0000-0002-8142-2867

\title{
Teatr w kalejdoskopie - od bajki do koszmaru (kilka uwag o roli teatru w trylogii Podwójny teatr Nikołaja Jewreinowa)
}

Słowa kluczowe: teoria, teatr, ułuda, koszmar, rola

Twórczość Nikołaja Jewreinowa w równym stopniu odzwierciedla przemiany teatru początku XX wieku i poglądy samego autora na jego istotę. Od początku swojej działalności twórczej autor-reżyser-znawca teatru w pierwszych, krótkich, „skrzących się dowcipem” jak pisał Nicoll, jednoaktówkach [Nicoll 1983, 207], przekazywał specyficzne, aczkolwiek mieszczące się nurcie ewolucji teatralnych pierwszego etapu Wielkiej Reformy ${ }^{1}$, teorie. W późniejszym okresie działalności artystycznej sztuki Jewreinowa zyskują kształt pełnowymiarowych dramatów, zachowując przy tym funkcje podwójną (jak było to $\mathrm{w}$ przypadku dramatów z pierwszego etapu): dzieła sztuki i jednocześnie specyficznie pojmowanej formy manifestu twórczego. Nie inaczej dzieje się w przypadku trylogii Podwójny teatr (Двойной meamp). powstającej w latach 1921 - То, со najważniejsze (Самое главное), 1924 Okręt sprawiedliwych (Корабль праведньх) (któremu zarzucano przewage efektów widowiskowych nad przedstawianymi ideami [http://rcin .org.pl/ibl/Content/39449/WA248_31204_P-II-217_zycie-teatr-1925_o.PDF])

\footnotetext{
1 Szerzej na temat teorii Prawodawców Reformy zob np.: Braun K. Wielka Reforma Teatru Ludzie-Idee-Zdarzenia. Wrocław-Warszawa....1984.
} 
i ostatniej części, stanowiącej jednocześnie podstawowy przedmiot niniejszych rozważań, Teatr wiecznej wojny (Teamp вечной войнь) z 1928 roku. Już daty powstania tekstów zwracają uwagę badacza. Pierwszy z nich bowiem należy jeszcze do „rosyjskiego" ${ }^{2}$ etapu Jewreinowa, został też w Rosji w 1921 roku wystawiony (20.02.1921 w Piotrogradzie w teatrze Wolna komedia). Wkrótce po powstaniu Okrętu sprawiedliwych, 30.01.1925 roku Jewreinow na zawsze opuścił Rosję. Ostatnia z części trylogii Podwójny teatr powstała już na emigracji, w Paryżu, jako jedno z nielicznych dramaturgicznych świadectw działalności autora.

Trylogia dramatyczna Podwójny teatr (a w szczególności jej pierwsza i trzecia część) stanowią manifest-egzemplifikację teorii autora - o roli teatru w życiu człowieka, ale też o sile samego teatru, jego mocy i pięknie, zapoczątkowanej już w Pięknym despocie (Kрасuвый дecnom). W sztuce tej, życie zostaje zamienione na teatr i toczy się według reguł teatru, jego podstawowego wyznacznika - jego uniwersum nie jest bowiem prawdziwe, a właśnie teatralne, sztuczne ${ }^{3}$. Główny bohater w swoim majątku ustanawia prawa i zwyczaje sprzed dwóch wieków, wybierając minioną epokę na swój świat i swoje uniwersum. Ten właśnie czas jest dla niego idealny, najlepszy, w nim czuje się bezpiecznie i pewnie. Wobec tego korzystając ze swoich możliwości upodabnia funkcjonującą wokół siebie przestrzeń do realiów czasu minionego, budując coś na kształt scenografii, która jednakże dla niego przekształca się w rzeczywistość. Również swoją służbę wtłacza w owe ramy, odcinając się tym samym od realnego życia. Zaczyna więc żyć w świecie teatralnym (rozumianym w najbardziej konwencjonalny sposób - czyli przeciwieństwo świata prawdziwego) kreując tym samym przestrzeń specyficznego teatru w teatrze (spektaklu). Sytuacja taka jest odwrotnością sceny zbudowanej chociażby w Czwartej ścianie (Четвёртая стена), i gdzie teatr ma stać się rzeczywistością - zaś biedny Faust (aktor) - bohater sztuki, zostaje zmuszony do funkcjonowania w świecie naśladującym rzeczywistość, wypełnioną rekwizytami z epoki. Bez możliwości wyboru, zostaje siłą wtłoczony w uniwersum teatru, które ma traktować jak świat rzeczywisty, naturalny. Kierując się konsekwencjami sposobu skonstruowania

2 Nikołaj Jewreinow opuścił Rosje już po zrealizowaniu swojego największego teatralnego dzieła - Szturmu Pałacu Zimowego. Wyjechał w 1925 roku. Na emigracji powstały tylko nieliczne dramaty i teksty poświęcone historii teatru. To w Rosji powstała przeważająca część dramaturgii autora.

3 Odwołujemy się tu do stwierdzenia Sławomira Świątka: teatr jako zjawisko możemy wyróżniać jedynie jako przeciwstawienie życia, to co teatralne dlatego właśnie tak określamy, ponieważ przeciwstawiamy mu to, co nieteatralne, które jest niczym innym, jak sferą życia. [Teatr Widowisko, 2000, 19). 
sztuki, czyli wykorzystaniem chwytu „teatru w teatrze”, autor wskazuje, iż postacie są częścią tego teatru, który powstał na życzenie Pana i zastępuje realne życie. Są to więc postacie podwójnie zorientowane: w pierwszym wymiarze to bohaterowie sztuki Jewreinowa Piękny despota, w drugim zaś osoby spektaklu odgrywanego w posiadłości Pana. Przed oczami odbiorcy pojawia się więc nieco inny niż znany z tradycji „teatr w teatrze”, nacechowany podwójną iluzorycznością. Teatralność wydarzeń odgrywanych na scenie została zwielokrotniona. Dekoracje grają dekoracje, a bohaterowie innych bohaterów. Nic nie jest prawdziwe, nic nie jest rzeczywiste. Spektakl grany na scenie jest też tylko spektaklem. Oczywiście, powstałym z wyboru, na życzenie, takim, w którym role zostały określone i przydzielone. Ów aspekt wybierania/przydzielania roli zaakcentowany został w momencie, w którym główny bohater, zwracając się do swojego przyjaciela, mówi: "Nie o to chodzi. Prosisz o artykuł Dobrego Siewcy, ale Dobry Siewca zawierzył społecznym ideałom i umarł z głodu. Dobry Siewca ustąpił miejsca Despocie. (...) Pięknemu despocie." [Евреинов 1908, T1, 349. Tłumaczenie moje - JG.] Pan świadomie gra Despotę, rolę, którą sam wybrał. W tym momencie i kilka kwestii później jednak Despota/Pan przestaje być tylko uczestnikiem wystawianego przez siebie spektaklu i na chwilę porzuca swoją rolę, spektakl „zatrzymuje się”, a Pan staje się postacią utworu Jewreinowa, a nie sztuki granej w dramacie. Niemniej jednak owe powroty do rzeczywistości, reprezentowanej przez Przyjaciela z dawnych lat, są jedynie chwilowe, jakby wymuszane. Można nawet odnieść wrażenie, że Pan wzbrania się przed nimi, że chce pozostać w świecie przez siebie stworzonym, gdzie przydzielił role, i aby go nie burzyć, zakazał dostarczania listów, które mogłyby spowodować pojawienie się w sztucznej rzeczywistości fragmentów tej prawdziwej. Zakłócenie spowodowane wtargnięciem elementów teraźniejszości mogłoby zachwiać pieczołowicie budowaną utopią, światem, w którym Piękny despota ma władzę absolutną. Do idei życia w owym sztucznym środowisku próbuje oczywiście przekonać swojego przyjaciela, rysując przed nim wszelkie atrakcje i piękno zbudowanego przez siebie świata. I tu znów akcentuje aspekt teatralności owego tworu. W momencie, w którym opowiada przyjacielowi o poranku spędzonym na przyjemnościach korzysta z czegoś w rodzaju dziennika, gdzie zapisane są jego wszelkie poczynania i emocje. Można nazwać to dziennikiem, jednak dokładność, z jaką odtwarzane są w nim wszelkie szczegóły dotyczące porządku dnia, wskazuje raczej na scenariusz, instrukcję według której postępować należy. Wszystko to składa się na powstanie w dramacie spektaklu, w który wchodzi i z którego może swobodnie wyjść jedynie Pan, zaś wszyscy inni odrywają w nim wcześniej przydzielone role. Sytuacja ta staje się egzemplifikacją podwójną. Z jednej 
strony jest to bowiem obraz teorii, w myśl której w życiu odgrywamy określone role a instynkt teatralności jest instynktem naturalnym, nieodłącznym ludzkiej naturze. $\mathrm{Z}$ drugiej jednak jest obrazem niebezpiecznym, choć tylko z punktu widzenia jednostki, bowiem kreacja rzeczywistości zastępuje tu rzeczywistość i niestety, nie widać powrotu do niej ani też nie ma tu eksplicytnie wyrażonych śladów budowania uniwersum scenicznego za pomocą chwytów teatrowi przynależnych.

Inaczej rzecz przedstawia się w dwóch tekstach należących do trylogii Podwójny teatr. Tu wszystko jest teatralne, odbywa się w teatralnym anturażu, powstaje za pomocą środków niezbędnych dla powstania iluzji scenicznej i co ważniejsze środków owych nie kamufluje, lecz raczej na odwrót są one wyeksponowane. To, co najważniejsze uznane zostało za egzemplifikacje teorii Jewreinowa, która w późniejszym okresie i po wielu przemianach i zmianie dziedziny pojawiała się jako jedna z bardziej popularnych metod psychoterapii - mianowicie w psychodramie ${ }^{4}$. Jak można bowiem twierdzić:

Główną tezą sztuki Jewreinowa jest myśl, że szczęście ludzie mogą znaleźć tylko w złudzeniu, ułudzie i kłamstwie, że teatr i życie to jedno, że jesteśmy wiecznymi komediantami i że w tym tylko powinniśmy szukać duchowych pociech. [Sielicki 1996, 179]

Dlatego też w pierwszej części trylogii Podwójny teatr spotykamy się z próbą stworzenia uniwersum szczęścia, ale zbudowanego/wykreowanego, by posłużyć się terminem Edwarda Gordona Craiga ${ }^{5}$, według metod i sposobów charakterystycznych nie tylko dla teatru. Punktem wyjścia dla funkcjonowania takiego uniwersum jest przedstawiona w pierwszych scenach wizyta w gabinecie wróżki-nie wróżki (w rzeczywistości udającego ją Dyrektora Fregollego). Wcielając się w postać wróżki - czyli tworząc pierwsze z teatralnych uniwersów - poznaje marzenia i troski odwiedzających ją bohaterów. Poznawszy je z kolei, postanawia pomóc bohaterom, stwarzając na scenie

4 Do teorii Jewreinowa nawiązuje Jakob Levi Moreno (Psychodrama, 1964) w stworzonej przez siebie metodzie psychodramy, w której: elementy teatru i dramy, polegająca na przygotowywaniu przez członków grupy terapeutycznej (lub klienta indywidualnego w przypadku monodramy) bez założonego scenariusza scen dotyczących rzeczywistości zewnętrznej lub świata wewnętrznego. Celem jest osiągnięcie jak najlepszego i elastycznego przystosowania jednostki do zmieniających się okoliczności, a także twórczy wpływ na tę rzeczywistość. Dramaterapia polega na odgrywaniu przez osobę różnych ról społecznych w zaimprowizowanych sytuacjach.

5 Edwarg Godron Craig, jeden z Prawodawców Wielkiej Reformy Teatru, w swoim dziele $O$ sztuce teatru (ukazało się w 1905 roku w Niemczech, w języku niemieckim), używa terminu ,geschaffen sein” wskazując jednoznacznie na konieczność kreacji uniwersum scenicznego, które z definicji nie może być mimetycznym odzwierciedleniem rzeczywistości. 
świat urzeczywistniający ich sny, angażując do odgrywania ról aktorów teatru. W akcie trzecim, którym padają znaczące słowa: „wszyscy jesteśmy aktorami u Pana Boga", bohaterowie, którym dyrektor Fregolli postanowił pomóc przeżyły (zrealizowały, choć tylko w teatrze) już swoją bajkę i wtopiły się teatralne tło. Trzeci akt to teatr w czystej formie - urzekający, ale i świadomy swej istoty. Pojawiają się w nim postacie rodem z commedia dell'arte wraz z Arlekinem i wieńczącym sztukę bengalskim ogniem. Finał sztuki jest więc triumfem teatru. Postacie są tego świadome i godzą się z prawami, które teatrem rządzą. Pozwala to na osiągniecie tzw. nowej równowagi (trzeciej fazy komedii). Bohaterowie spełniają swoje marzenia, są szczęśliwi. Nie ma potrzeby zmieniania czegokolwiek, teatr może trwać, bowiem wszystkie postacie sztuki (pozornie - metodami teatralnymi uszczęśliwione), zaczynają w nim uczestniczyć. Nie wiedzą, że ich radość wynika z teatralnej ułudy, że cieszy ich sztuczna, teatralna, wykreowana rzeczywistość, która tak naprawdę nie istnieje. Nie muszą się o tym dowiedzieć, nie rozwiąże to ich problemów. W planie komedii wszyscy zostają aktorami i osiągają nową równowagę. I to stanowi koniec sztuki. Wszyscy są zadowoleni, ale wszyscy są w teatrze.

Teatralizacja życia Jewreinowa daje więc bohaterom pierwszej części trylogii szczęście i spełnienie. Nie jest tu ważne, czy stan ten został osiągnięty dzięki osobistej pracy, zwrotowi losu czy też, jak ma to miejsce w tym przypadku dzięki działalności dyrektora teatru i odegraniu roli przez wynajętego w tym celu aktora. To, co najważniejsze daje szczęście swoim bohaterom. Jest więc pozytywną egzemplifikacją działania teatralizacji życia i ułudy świata, który teatr ten kreuje. Nie budzi rozczarowania, ani też bólu. Pomaga wejść do innego świata bez cierpienia i rozczarowania. Bycie w teatrze i granie roli nie rozczarowuje, daje szczęście i dopełnienie, nie rani nikogo, później zaś pozwoli odnaleźć się w nowych realiach.

Zupełnie inaczej jest $\mathrm{w}$ przypadku zamykającej trylogię części, czyli $\mathrm{w}$ Teatrze wiecznej wojny. Jej ostatnia scena - zatytułowana Bal demasque jest odwrotnością końcowej sceny pierwszej części. W obydwu dramatach środkiem wyzwalającym poznanie ukrytych pragnień może być hipnoza - to dzięki niej dyrektor Fregolli poznaje skrywane potrzeby swoich klientów, by później je spełnić, prowadząc do teatralnego happy endu. W części ostatniej jednak - w Teatrze wiecznej wojny - hipnoza nie ma konotacji pozytywnej, jest raczej czymś w rodzaju przejawu władzy nad świadomością człowieka, siłą zmuszającą go do mówienia i robienia tego, czego życzy sobie inna silniejsza osoba. Oczywiście w tym przypadku niezwykle znamienne wydaje się również i to, iż osoba, która owej hipnozy używa sama znajduje się we władzy używki - mianowicie opium. 
Sytuacja więc jest w tym przypadku krańcowo różna - nie można mówić o czystych intencjach, tym bardziej, że tematem sztuki są losy uczniów Instytutu Teatralnego, w którym Pyszna Dyrektorowa naucza odgrywania roli i ukrywania tego, co w człowieku prawdziwe. Metoda przyjęta przez Dyrektorową bazuje więc na nauczeniu udawania - stłamszeniu naturalnych instynktów, uczuć i pragnień i dostosowania się - wejścia w określoną przez otoczenie i korzystną rolę. Brakuje więc tu chociażby cienia chęci pomocy, jest coś wręcz przeciwnego - stworzenie sztucznego świata nie służy zbudowaniu szczęśliwej bajki, lecz wyzyskaniu sprzyjających warunków, nauczeniu skrywania prawdziwych uczuć, gdyż zadaniem Dyrektorowej to, co naturalne, winno być wyrugowane. $\mathrm{W}$ konsekwencji więc jest to pewnego rodzaju odarcie człowieka (tu uczniów) z ludzkich emocji i pragnień, w miejsce których zostaną wtłoczone zachowania wynikające z narzuconej roli. Człowiek staje się raczej Schopenchauerowską marionetką, bezwolną i uzależnioną od najróżniejszych czynników, tym bardziej, że w końcowej scenie sztuki czasie owego bal demasque aktorzy wypowiadają kwestie przez Pyszną Dyrektorową nieoczekiwane, a wręcz wobec niej wrogie, choć nie do końca wiadomo, czy są to ich słowa, czy też po prostu gra. Czynią to najprawdopodobniej pod wpływem hipnozy innej postaci sztuki. O ich hipnotycznym transie/przebywaniu w stanie zmienionej świadomości, poddaniu się woli innego czynnika ${ }^{6}$, świadczyć może zakończenie sceny, w którym postacie wybudzone z transu wracają do rzeczywistości nieświadome tego, co się wydarzyło. Scena ta jednak nie do końca jest tak jednoznaczna - wcześniej bowiem ci sami bohaterowi, dyskutując o nadchodzącym wydarzeniu obnażali swoje prawdziwe twarze. Można więc postawić pytanie - na ile hipnoza stała się dla nich czynnikiem implikującym narzucone zachowanie a na ile była jedynie środkiem pozwalającym na pełne odkrycie swojej twarzy?

6 Brytyjskie Towarzystwo Medyczne definiuje hipnozę jako: przejściowy stan zmienionej uwagi, w którym mogą pojawiać się różne zjawiska spontanicznie bądź jako reakcje na werbalne lub inne bodźce. Inna definicja mówi zaś: Stan świadomości obejmujący zwiększony stan koncentracji i zmniejszenie świadomości peryferyjnej charakteryzujący się zwiększoną zdolnością do przyjmowania sugestii. [https://hypnosisandsuggestion.org/co-to-jesthipnoza.html]. Część badaczy uznaje hipnozę za stan zmienionej świadomości odmienny zarówno od stanu czuwania jak i snu. W stosunku do stanu czuwania, podkreśla się takie odmienności hipnozy, jak obniżenie zdolności planowania, nierozdzielność uwagi, możliwość przywoływania wspomnień wzrokowych lub wyobrażeń, wzrost zdolności do wytwarzania nowych wyobrażeń lub fantazji, ograniczoną zdolność do prawidłowej oceny realności, zwiększoną sugestywność, skłonność do zachowań zgodnych z przyjętą rolą oraz niepamięć tego wszystkiego, co działo się podczas stanu hipnozy [Jerzy W. Aleksandrowicz: Hipnoza. Kraków: PAN, 1973, s. 9]. Zwłaszcza ostatnia z przywołanych definicji odzwierciedla stan i losy bohaterów ostatniej części trylogii Podwójny teatr. 
Idąc dalej tym tropem należy się zastanowić, na ile hipnoza Ju dzin li działała, a na ile była jedynie formalnym chwytem teatralnym anturażem, który był de facto jedynie formą kamuflażu, bez którego nie doszłoby do zupełnego obnażenia prawdziwych uczuć i pragnień uczestników szkolenia w instytucie teatralnym i została jedynie przez aktorów/uczniów odegrana. Sytuacja więc staje się karykaturą teorii zawartej w Tym, co najważniejsze. W pierwszej sztuce trylogii jak można podejrzewać, teatr stał się formą terapii, odsłaniał i jednocześnie spełniał najskrytsze marzenia, przy okazji czyniąc poddane tej specyficznej formie terapii osoby bardziej pewnymi siebie i szczęśliwszymi. Jednocześnie jednak, zamykał je na zawsze w świecie teatru, wskazując, że w każdej chwili swego życia świadomie lub mniej świadomie odgrywamy określoną/przeznaczoną rolę. Wszystko to jednak nie miało cech fałszywych, sztucznych i co najważniejsze nie było nacechowane negatywnymi emocjami. Nie służyło ani zranieniu osób bliskich ani też odsłonieniu najdzikszych instynktów. W ostatniej części dzieje się inaczej, jak gdyby po raz kolejny Jewreinow spojrzał na teatr z drugiej strony i przypomniał wszystkim, że za zapomnienie o tym, że jest się w teatrze, za zachwyt jego pięknem płaci się cenę wysoką. Tu ową ceną jest podwójność sytuacji i możliwych rozwiązań, ciągła niepewność i zawieszenie w wiecznym niepoznaniu.

Pewna doza umiejętności udawania jest niezbędna. I każdy z ludzi funkcjonując w rzeczywistości ową rolę przybiera i ją odgrywa. Wykorzystując naturalny instynkt teatralności można doprowadzić do tego, że dana osoba przestaje pokazywać siebie i swoje emocje (to co naturalne) na rzecz maski (tego, co sztuczne). To pierwszy konflikt dziejący się na scenie odwiecznego teatru wojny. Ale przecież w sztuce widzimy znacznie więcej. Ludzi, którzy są zmuszeni, wbrew swojej woli do odgrywania innej roli niż wybrana przez siebie, lub też dla siebie najlepsza. I takich też, którzy swoim postępowaniem potrafią na tyle zmanipulować rzeczywistość, by otaczające je postacie biernie wykonywały ich polecenia lub spełniały życzenia. I nie do końca wiadomo, jakie są naprawdę. Ostatnia scena jednak, ta w której poddane hipnozie postacie wypowiadają posłuszeństwo pysznej Dyrektorowej otwiera drugą możliwość interpretacji. Pierwsza jest oczywista - postacie zostały zahipnotyzowane i są jedynie marionetkami w rękach Ju dzin li. Jest jednak jeszcze jedna możliwość: bohaterowie, uczniowie instytutu, oszukują podwójnie: że zostały poddane hipnozie i że jedynie grają rolę. W rzeczywistości urządzają dla nieświadomych niczego Ju Dzin li i Pysznej Dyrektorowej widowisko, w którym paradoksalnie mówią prawdę, udając, że jest to rola, odsłaniają prawdziwe uczucia i emocje, które widzom wydają się jedynie maską i częścią większego planu. W tym wypadku więc teatr nie 
udaje rzeczywistości, kreując ułudę i bajkę, ale rzeczywistość staje się teatrem, czyli miejscem gdzie można ukazać siebie bez maski. Odwrócenie ról - teatru i rzeczywistości jest szokującym zabiegiem, zamkniętym jednak, jak zawsze dzieje się to u Jewreinowa w klamrę sceniczności. Teatr balu demasque kończy się w oparach opium. Wszystko znowu staje się nierealne, sztuczne, wykreowane - ale straszne, nie jest już snem - pierwotnej fazy reformowania teatru, lecz staje się koszmarem ekspresjonistycznych eksperymentów scenicznych ${ }^{7}$. Świadomy owej zmiany widz pozostaje z otwartym pytaniem: o granice teatralności w życiu i prawdę otaczającej rzeczywistości. Ale jak zawsze u Jewreinowa pozostaje w teatrze, którego winien być świadomy, ale i czuć przed nim respekt.

\section{Literatura}

Aleksandrowicz J. W., 1973, Hipnoza, Kraków.

Bab J., 1953, Teatr wspótczesny, przeł. E. Misiołek. Warszawa.

Bablet B., 1973, Wspótczesna reżyseria, Warszawa.

Bablet D., 1980, Rewolucje sceniczne XX wieku, przeł. Z. Strzelecki. K. Mazur, Warszawa.

Balcerzan E., 1982, Ekspresjonizm jako poetyka, w: idem, Kregi wtajemniczenia. Czytelnik. Badacz. Ttumacz. Pisarz, Kraków.

Braun. K., 1984, Wielka Reforma Teatru. Ludzie - Idee - Zdarzenia, Wrocław Warszawa - Kraków - Gdańsk.

Brauneck M., 1993-2005, Die Welt als Bühne.Geschichte des europäischen Theaters. T 1-5. Stuttgart - Weimar.

Ekspresjonizm w teatrze europejskim, 1983, przeł. A. Choińska, K. Choiński, E. Radziwiłłowa, Warszawa.

Gracla J., 2013, Dramat wobec sceny. Echa ewolucji teatru europejskiego w dramaturgii pierwszego trzydziestolecia XX wieku, Katowice.

Gracla J., 2015, Dramaturgia Mikotaja Jewreinowa na emigracji (Co nie ma imienia, albo co śnito się biednej dziewczynie - eksperyment z forma), [w:] Stowianie na emigracji. Literatura - Kultura - Język, red. B. Kodzis, M. Giej. Opole, 261-269.

Jewreinow N., 1947, Histoire du théâtre russe, Paris.

Jewreinow N., 1946, Le théâtre en Russie Soviétique, Paris.

Jewreinow N., 1927, The theatre in life, New York; London.

7 Na temat eksperymentów teatru ekspresjonistów zob: J. Bab, Teatr współczesny, 1953;

D. Bablet, Rewolucje sceniczne XX wieku, 1980 i in. 
Jewreinow N., 1953, Istoriâ russkogo teatra [История русского meampa], Н.-И. Kodzis B., 2007, Teatral'nâa deâtel'nost' Nikolâ̂ Evreinova [w:] Kultura rosyjska w ојсzуźnie i diasporze, Kraków, s. 347-355. [Театральная деятельность Николая Евреинова, [w:] Kultura rosyjska w ojczyźnie i diasporze, Kraków, s. 347-355.]

Nicoll A., 1983, Dzieje dramatu, przeł. H. Krzeczkowski, W. Niepokólczycki, J. Nowacki, Warszawa.

Pavis P., 1998, Stownik terminów teatralnych, przeł. S. Świontek, Wrocław.

Problemy teorii dramatu i teatru, 2003, red. J. Degler, Wrocław.

Sielicki F., 1996, Pisarze rosyjscy poczatku XX wieku w Polsce międzywojennej, Wrocław.

Teatr Widowisko, 2000, red. M. Fik, Warszawa.

Annenkov U.., 1966, Dnevniki moih vstreč. Cikl tragedij, New York. [Анненков Ю., Дневники моих встреч. Цикл трагедий, New York.]

Babenko V. G., 1992., Arlekin, Izd. Ural'skogo universiteta [Бабенко В. Г., Apлекин, Изд. Уральского университета].

Evreinov N., 1908-1923, Dramatičeskie sočineniâ. T. 1-3, Sankt Peterburg. [Евреинов Н., 1908-1923, Драматические сочинения, Т. 1-3. Санкт Петербург].

Evreinov N., 1928, Teatr večnoj vojny. [Евреинов Н., 1928, Театр вечной войньг.]

THEATER IN A KALEIDOSCOPE - FROM A FAIRY TALE TO A NIGHTMARE (A FEW REMARKS ON THE ROLE OF THEATER IN THE NIKOLAI YEVREINOV'S DOUBLE THEATER TRILOGY)

ABSTRACT

In the presented sketch, the author indicates the problem of changing the approach to the role of theater in human life in three works by Nikolai Yevreinov: A Beautiful Despot, What is Most Important and The Theater of Eternal War. The author initially perceives theater as an attempt to build an artificial reality for his own convenience and whim, so it is an escape from reality. In subsequent plays, his image changes - at first it becomes a beautiful fairy tale, an attempt at therapy and making people happy using theatrical methods. In the final part of the Double Theater trilogy, it becomes a method of revealing the true face. However, as the author points out, this is not the only way to understand the role of theater - it can also be just theater - another artificial reality.

Key words: theory, theater, delusion, nightmare, role 